\title{
PENGARUH KOMBINASI PUPUK KOMPOS DAN NPK TERHADAP PERTUMBUHAN, JUMLAH KLOROFIL $a$ DAN KADAR AIR Gracilaria verrucosa
}

\section{EFFECT OF COMPOST AND NPK FERTILIZER COMBINATIONS ON GROWTH, CHLOROPHYLL $a$ AND WATER CONTENT OF Gracilaria verrucosa}

\author{
Mochammad Amin Alamsjah, Iva Nur Silviana dan Kadek Rachmawati \\ Fakultas Perikanan dan Kelautan Universitas Airlangga \\ Kampus C Mulyorejo - Surabaya, 60115 Telp. 031-5911451
}

\begin{abstract}
In general, Gracilaria culture still using organic and inorganic fertilizer single. Organic or inorganic fertilizer applied is felt have not yet enough to support the growth of Gracilaria. The aim of this experiment was to know the best compost and NPK combinations which could influence on growth, chlorophyll a and water content of G.verrucosa. Treatment applied was compost and NPK combinations with different doses, that is A treatment $(0 \mathrm{gr} / 1$ : $2 \mathrm{gr} / 1)$, B treatment $(0,5 \mathrm{gr} / 1: 1,5 \mathrm{gr} / 1), \mathrm{C}$ treatment $(1 \mathrm{gr} / 1: 1 \mathrm{gr} / 1)$, D treatment $(1,5 \mathrm{gr} / 1: 0,5 \mathrm{gr} / 1)$, E treatment $(2 \mathrm{gr} / 1: 0$ $\mathrm{gr} / \mathrm{l}$ ) and $\mathrm{F}$ treatment (without fertilizer), each treatment was replicated 4 times. Main parameter observed was daily growth rate (\%/day), relative length growth (\%), chlorophyll $a(\mu \mathrm{g} / \mathrm{ml})$ and water content $(\%)$ of G.verrucosa. Supported parameter observed was $\mathrm{pH}$, temperature $\left({ }^{\circ} \mathrm{C}\right)$ and salinity $(\% 0)$. Data analysis using Analysis of Variance (ANOVA) and Duncan Multiple Range Test. Result of the experiment indicates that compost and NPK combinations with different doses was significantly influence to growth, chlorophyll $a$ and water content of $G$. verrucosa. The highest mean of daily weight growth rates was $C$ treatment $(1 \mathrm{gr} / 1: 1 \mathrm{gr} / \mathrm{l})$ which was equal to $2,56 \%$ /day and the lowest mean was $\mathrm{F}$ treatment (without fertilizer) which was equal to $1,12 \% /$ day. The highest mean of relative length growth was $\mathrm{C}$ treatment $(1 \mathrm{gr} / 1: 1 \mathrm{gr} / \mathrm{l})$ which was equal to $2,21 \%$ and the lowest mean was $\mathrm{F}$ treatment (without fertilizer) which was equal to $0,60 \%$. The highest mean of chlorophyll $a$ by the end of the experiment was C treatment ( $1 \mathrm{gr} / 1: 1 \mathrm{gr} / \mathrm{l}$ ) which was equal to $0,001948 \mu \mathrm{g} / \mathrm{ml}$ and the lowest mean was $\mathrm{F}$ treatment (without fertilizer) which was equal to $0,001440 \mu \mathrm{g} / \mathrm{ml}$. The lowest mean of water content by the end of the experiment was $\mathrm{C}$ treatment $(1 \mathrm{gr} / 1: 1 \mathrm{gr} / \mathrm{l}$ ) which was equal to $28,48 \%$ and the highest mean was $\mathrm{F}$ treatment (without fertilizer) which was equal to $30,39 \%$.
\end{abstract}

Key words : Gracilaria verrucosa, compost, NPK, growth, chlorophyll $a$, water content

\section{Pendahuluan}

Rumput laut merupakan salah satu komoditas kelautan dan perikanan yang potensial. Salah satu jenis rumput laut yang banyak ditemukan di perairan Indonesia adalah $G$. verrucosa dan merupakan penghasil agar (Lewmanomont, 1995). Budidaya Gracilaria pada umumnya menggunakan pupuk organik dan pupuk anorganik secara tunggal. Penggunaan pupuk organik atau pupuk anorganik saja dirasa belum cukup untuk menunjang pertumbuhan Gracilaria. Hal ini dikarenakan pupuk organik hanya mengandung beberapa unsur hara makro dan unsur hara mikro, sedangkan pupuk anorganik mengandung unsur hara makro dengan jumlah banyak dan tanpa unsur hara mikro (Indriani, 2000).

Berdasarkan uraian di atas maka diperlukan suatu alternatif metode budidaya yang dapat memperkecil kendala tersebut. Alternatif metode untuk memperkecil kendala penggunaan pupuk organik dan anorganik secara tunggal adalah dengan digunakan kombinasi pupuk organik dan anorganik. Pada penelitian ini, pupuk organik yang digunakan adalah pupuk kompos sedangkan pupuk anorganik yang digunakan adalah NPK. Pupuk kompos memiliki unsur hara yang lengkap tetapi jumlahnya sedikit, sedangkan NPK mengandung unsur hara $\mathrm{N}, \mathrm{P}$ dan $\mathrm{K}$ dengan jumlah banyak (Salundik dan Simamora, 2006). Metode budidaya rumput laut $G$. verrucosa menggunakan kombinasi pupuk kompos dan NPK merupakan solusi untuk peningkatan efisiensi lahan, waktu dan modal, serta diharapkan dapat mempengaruhi pertumbuhan, jumlah klorofil $a$ dan kadar air G. verrucosa lebih baik daripada budidaya di tambak.

Tujuan penelitian ini adalah untuk mengetahui dosis kombinasi terbaik dari kombinasi pupuk kompos dan NPK yang dapat mempengaruhi pertumbuhan, jumlah klorofil $a$ dan kadar air $G$. verrucosa.

Penelitian ini diharapkan dapat memberikan informasi tentang dosis kombinasi pupuk kompos dan NPK yang menghasilkan pertumbuhan dan jumlah klorofil $a$ tertinggi serta kadar air terendah pada G. verrucosa. 


\section{Materi dan Metode Penelitian}

Penelitian ini dilaksanakan pada tanggal 1 Oktober - 10 November 2008 di Jl. Bendul Merisi 87 Surabaya, Laboratorium Kesehatan Masyarakat Veteriner, Laboratorium Patologi Klinik Fakultas Kedokteran Hewan Universitas Airlangga Surabaya, tambak budidaya rumput laut di Desa Pulokerto, Kecamatan Kraton, Kabupaten Pasuruan dan pada tanggal 10 November 2008 - 13 November 2008 di Laboratorium Makanan Ternak Fakultas Kedokteran Hewan Universitas Airlangga Surabaya dan Laboratorium Pengujian dan Kalibrasi Baristand Surabaya.

Peralatan yang digunakan dalam penelitian ini adalah 24 unit akuarium berukuran $(50 \times 10 \times 15) \mathrm{cm} 3$, tandon air laut, selang aerasi, batu aerasi, batu karang, pompa aerasi, lampu fluorescent 40 Watt, plastik hitam, pompa $1200 \mathrm{~kW}$, tali, pipa PVC, round cuvet, tabung reaksi, pipet, oven, timbangan digital, refraktometer, termometer, $\mathrm{pH}$ indikator universal dan spektrofotometer. Bahan penelitian yang digunakan adalah G. verrucosa, air laut 30\% pupuk kompos dan NPK.

Metode penelitian yang digunakan dalam penelitian ini adalah metode experimental menggunakan Rancangan Acak Lengkap (RAL) dengan enam perlakuan dan empat ulangan :
A : pupuk kompos : NPK dengan persentase kombinasi $0 \%$ : $100 \%(0 \mathrm{gr} / 1: 2 \mathrm{gr} / \mathrm{l})$
B : pupuk kompos : NPK dengan persentase kombinasi $25 \%: 75 \%(0,5 \mathrm{gr} / 1: 1,5 \mathrm{gr} / 1)$
$\mathrm{C}$ : pupuk kompos : NPK dengan persentase kombinasi $50 \%$ : 50\% (1 gr/l : $1 \mathrm{gr} / \mathrm{l})$
D : pupuk kompos : NPK dengan persentase kombinasi $75 \%: 25 \%(1,5 \mathrm{gr} / 1: 0,5 \mathrm{gr} / 1)$
E : pupuk kompos : NPK dengan persentase kombinasi 100\% : 0\% (2 gr/1 : 0 gr/l)
$\mathrm{F}$ : tanpa pupuk (kontrol)

Parameter utama yang diukur adalah Pertumbuhan (berat dan panjang) setiap tujuh hari sekali, jumlah klorofil a dan kadar air G. verrucosa pada awal dan akhir penelitian.

Laju pertumbuhan harian (Daily Growth Rate)

$$
\text { DGR }(\text { berat })=\frac{(\ln \mathrm{Wt}-\ln \mathrm{Wo})}{\mathrm{t}} \times 100 \%
$$

Keterangan :

DGR $=$ persentase berat rata-rata individu per hari (\%/hari)

$\mathrm{Wt}=\ln$ berat rata-rata pada waktu ke-t (gram)
Wo $=\ln$ berat rata-rata awal (gram)

$\mathrm{t}=$ waktu (hari)

Pertumbuhan panjang relatif

$$
\mathrm{h}=\frac{(\mathrm{Lt}-\mathrm{Lo})}{\mathrm{Lo}} \times 100 \%
$$

Keterangan :

$\mathrm{h}=$ pertumbuhan panjang relatif $(\%)$

Lt = panjang rata-rata pada akhir pemeliharaan (cm)

Lo = panjang rata-rata pada awal pemeliharaan $(\mathrm{cm})$

Jumlah Klorofil $a$

Klorofil $a=11.6($ Abs 665) -1.31 (Abs

645) -0.14 (Abs 630)

$\mu$ mol klorofil dalam ekstrak $=\frac{\mu \mathrm{g} \text { klorofil dalam absorban }}{\text { berat molekul klorofil }}$

Berat molekul klorofil $a$ adalah 894 .

Kadar air

$$
\mathrm{KA}=\frac{(\mathrm{M} 2-\mathrm{M} 3)}{(\mathrm{M} 2-\mathrm{M} 1)} \times 100 \%
$$

Keterangan :

$\mathrm{KA}=$ kadar air

$\mathrm{M} 1=$ berat wadah sebelum dioven $(\mathrm{g})$

M2 = berat wadah + sampel sebelum dioven $(\mathrm{g})$

M3 = berat wadah + sampel setelah dioven $(\mathrm{g})$

\section{Hasil dan Pembahasan}

Pertumbuhan Gracilaria verrucosa

Hasil penelitian pengaruh kombinasi pupuk kompos dan NPK pada Gracilaria verrucosa, diperoleh data pertumbuhan G. verrucosa. Data tersebut diperoleh dari pengamatan dan pengukuran setiap seminggu sekali selama 35 hari. Pengamatan dan pengukuran terbagi menjadi dua bagian, yaitu laju pertumbuhan berat harian dan pertumbuhan panjang relatif.

Laju pertumbuhan berat harian

Hasil penghitungan Anova menunjukkan kombinasi pupuk kompos dan NPK berpengaruh nyata $(\mathrm{p}<0,05)$ terhadap laju pertumbuhan berat harian $G$. verrucosa. Hasil tersebut dilanjutkan dengan uji jarak berganda Duncan, yang menunjukkan bahwa kombinasi pupuk kompos dan NPK yang dapat memberikan laju pertumbuhan berat harian $G$. verrucosa terbaik adalah perlakuan C (pupuk kompos dan NPK = 1gr/l : 1gr/l) yang berbeda nyata $(\mathrm{p}<0,05)$ dengan perlakuan $\mathrm{B}$ (pupuk kompos dan NPK = 0,5 gr/1 : 1,5 gr/l) dan perlakuan $\mathrm{D}$ (pupuk kompos dan NPK $=1,5 \mathrm{gr} / 1: 0,5 \mathrm{gr} / \mathrm{l}$ ). 
Hasil terendah diperoleh perlakuan F (tanpa pupuk) yang tidak berbeda nyata $(p>0,05)$ dengan perlakuan A (pupuk kompos dan NPK $=0$ gr/l : 2 gr/l) dan perlakuan E (pupuk kompos dan NPK $=2$ gr/l : 0 gr/l). Hasil uji jarak berganda Duncan terhadap pertumbuhan berat rata-rata $G$. verrucosa pada setiap perlakuan terdapat pada Tabel 1 .

Laju pertumbuhan berat harian rata-rata G. verrucosa pada akhir penelitian adalah perlakuan A (1,36\%/hari), perlakuan B (1,86 $\% /$ hari), perlakuan C $(2,56 \% /$ hari $)$, perlakuan D $(1,82 \% /$ hari $)$, perlakuan E $(1,19 \% /$ hari $)$ dan perlakuan F (1,12\%/hari). Hasil pengukuran berat rata-rata $G$. verrucosa yang dilakukan setiap minggu pengamatan selama penelitian, terdapat pada Gambar 1 .

Pertumbuhan panjang relatif

Hasil penghitungan Anova menunjukkan kombinasi pupuk kompos dan NPK berpengaruh nyata $(\mathrm{p}<0,05)$ terhadap pertumbuhan panjang relatif G. verrucosa. Hasil tersebut dilanjutkan dengan uji jarak berganda Duncan yang menunjukkan bahwa kombinasi pupuk kompos dan NPK yang dapat memberikan laju pertumbuhan panjang harian G. verrucosa terbaik adalah perlakuan C (pupuk kompos dan NPK $=1 \mathrm{gr} / 1$ : $1 \mathrm{gr} / \mathrm{l})$ yang berbeda nyata $(\mathrm{p}<0,05)$ dengan perlakuan B (pupuk kompos dan NPK $=0,5 \mathrm{gr} / 1$ : 1,5 gr/l), perlakuan D (pupuk kompos dan NPK = $1,5 \mathrm{gr} / 1: 0,5 \mathrm{gr} / \mathrm{l}$ ) dan perlakuan E (pupuk kompos dan NPK = 2 gr/l : 0 gr/l). Hasil terendah diperoleh perlakuan $\mathrm{F}$ (tanpa pupuk) yang berbeda nyata $(\mathrm{p}<0,05)$ dengan perlakuan A (pupuk kompos dan $\mathrm{NPK}=0 \mathrm{gr} / 1: 2 \mathrm{gr} / \mathrm{l})$. Hasil uji jarak berganda Duncan terhadap pertumbuhan panjang relatif $G$. verrucosa pada setiap perlakuan terdapat pada Tabel 2.

Tabel 1. Hasil uji jarak berganda Duncan terhadap laju pertumbuhan berat rata-rata G. verrucosa selama 35 hari

\begin{tabular}{|l|c|c|}
\hline \multicolumn{1}{|c|}{ Perlakuan } & $\begin{array}{c}\text { Laju Pertumbuhan berat } \\
\text { rata-rata }(\% / \text { hari })\end{array}$ & $\begin{array}{c}\text { Pertumbuhan berata rata - } \\
\text { rata (transformasi } / \text { Y) }\end{array}$ \\
\hline $\mathrm{A}(\mathrm{Kmp}: \mathrm{NPK}=0 \mathrm{gr} / 1: 2 \mathrm{gr} / \mathrm{l})$ & 1,36 & $1,16^{\mathrm{c}}$ \\
$\mathrm{B}(\mathrm{Kmp}: \mathrm{NPK}=0,5 \mathrm{gr} / 1: 1,5 \mathrm{gr} / \mathrm{l})$ & 1,86 & $1,36^{\mathrm{b}}$ \\
$\mathrm{C}(\mathrm{Kmp}: \mathrm{NPK}=1 \mathrm{gr} / 1: 1 \mathrm{gr} / \mathrm{l})$ & 2,56 & $1,60^{\mathrm{a}}$ \\
$\mathrm{D}(\mathrm{Kmp}: \mathrm{NPK}=1,5 \mathrm{gr} / 1: 0,5 \mathrm{gr} / \mathrm{l})$ & 1,82 & $1,35^{\mathrm{b}}$ \\
$\mathrm{E}(\mathrm{Kmp}: \mathrm{NPK}=2 \mathrm{gr} / 1: 0 \mathrm{gr} / \mathrm{l})$ & 1,19 & $1,09^{\mathrm{c}}$ \\
$\mathrm{F}(\mathrm{Kmp}: \mathrm{NPK}=$ tanpa pupuk$)$ & 1,12 & $1,06^{\mathrm{c}}$ \\
\hline
\end{tabular}

Keterangan: Superskrip yang berbeda menunjukkan perbedaan $(\mathrm{p}<0,05)$

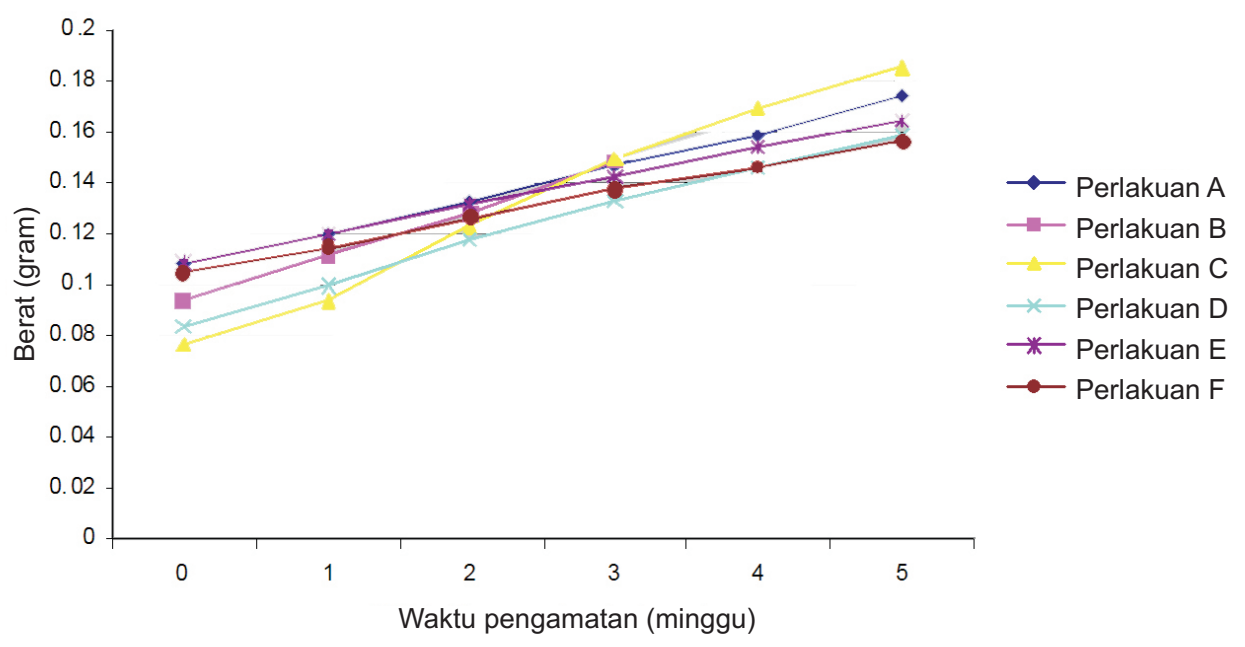

Gambar 1. Pertumbuhan berat G. verrucosa selama 35 hari ( Ket : A : (Kmp : $\mathrm{NPK}=0 \mathrm{gr} / 1: 2 \mathrm{gr} / \mathrm{l}), \mathrm{B}:(\mathrm{Kmp}: \mathrm{NPK}=0,5 \mathrm{gr} / 1: 1,5 \mathrm{gr} / \mathrm{l}), \mathrm{C}:$ $(\mathrm{Kmp}: \mathrm{NPK}=1 \mathrm{gr} / 1: 1 \mathrm{gr} / \mathrm{l}), \mathrm{D}:(\mathrm{Kmp}: \mathrm{NPK}=1,5 \mathrm{gr} / 1: 0,5 \mathrm{gr} / \mathrm{l})$, $\mathrm{E}:(\mathrm{Kmp}: \mathrm{NPK}=2 \mathrm{gr} /: 0 \mathrm{gr} / \mathrm{l}), \mathrm{F}:$ tanpa pupuk $)$ 
Tabel 2. Hasil uji jarak berganda Duncan terhadap pertumbuhan panjang rata-rata G. verrucosa selama 35 hari

\begin{tabular}{|l|c|c|}
\hline \multicolumn{1}{|c|}{ Perlakuan } & $\begin{array}{c}\text { Pertumbuhan } \\
\text { panjang relatif }\end{array}$ & $\begin{array}{c}\text { Pertumbuhan panjang relatif } \\
\text { rata - rata (transformasiv Y) }\end{array}$ \\
\hline $\mathrm{A}(\mathrm{Kmp}: \mathrm{NPK}=0 \mathrm{gr} / 1: 2 \mathrm{gr} / \mathrm{l})$ & 1,37 & $1,17^{\mathrm{b}}$ \\
$\mathrm{B}(\mathrm{Kmp}: \mathrm{NPK}=0,5 \mathrm{gr} / 1: 1,5 \mathrm{gr} / \mathrm{l})$ & 1,65 & $1,28^{\mathrm{b}}$ \\
$\mathrm{C}(\mathrm{Kmp}: \mathrm{NPK}=1 \mathrm{gr} / 1: 1 \mathrm{gr} / \mathrm{l})$ & 2,21 & $1,49^{\mathrm{a}}$ \\
$\mathrm{D}(\mathrm{Kmp}: \mathrm{NPK}=1,5 \mathrm{gr} / 1: 0,5 \mathrm{gr} / \mathrm{l})$ & 1,56 & $1,24^{\mathrm{b}}$ \\
$\mathrm{E}(\mathrm{Kmp}: \mathrm{NPK}=2 \mathrm{gr} / 1: 0 \mathrm{gr} / 1)$ & 1,46 & $1,2^{\mathrm{b}}$ \\
F (Kmp : NPK $=$ tanpa pupuk) & 0,60 & $0,76^{\mathrm{c}}$ \\
\hline
\end{tabular}

Keterangan: Superskrip yang berbeda menunjukkan perbedaan $(\mathrm{p}<0,05)$

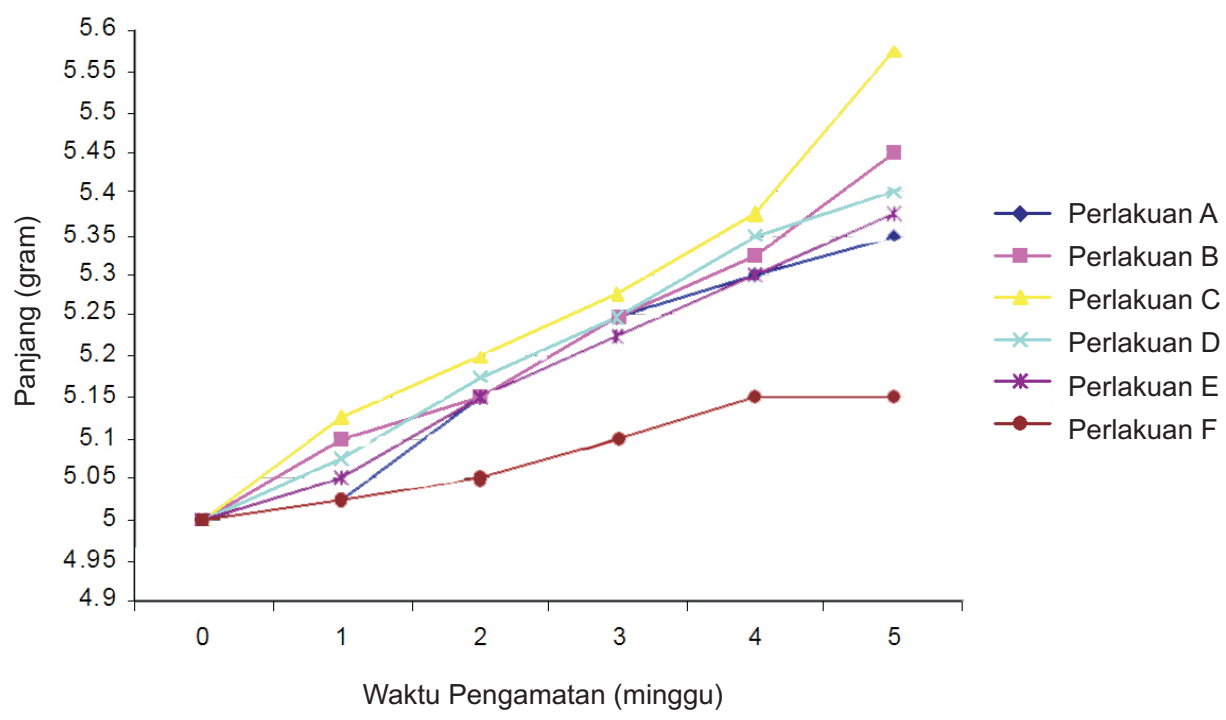

Gambar 2. Pertumbuhan panjang G. verrucosa selama 35 hari ( Ket : A : (Kmp $: \mathrm{NPK}=0 \mathrm{gr} / 1: 2 \mathrm{gr} / \mathrm{l}), \mathrm{B}:(\mathrm{Kmp}: \mathrm{NPK}=0,5 \mathrm{gr} / 1: 1,5 \mathrm{gr} / \mathrm{l}), \mathrm{C}:$

$(\mathrm{Kmp}: \mathrm{NPK}=1 \mathrm{gr} / 1: 1 \mathrm{gr} / \mathrm{l}) \mathrm{D}:(\mathrm{Kmp}: \mathrm{NPK}=1,5 \mathrm{gr} / 1: 0,5 \mathrm{gr} / \mathrm{l}), \mathrm{E}$ $:(\mathrm{Kmp}: \mathrm{NPK}=2 \mathrm{gr} /: 0 \mathrm{gr} / \mathrm{l}), \mathrm{F}:$ tanpa pupuk)

Tabel 3. Hasil uji jarak berganda Duncan terhadap jumlah klorofil a G. verrucosa

\begin{tabular}{|l|c|c|}
\hline \multicolumn{1}{|c|}{ Perlakuan } & $\begin{array}{c}\text { Jumlah klorofil } a \text { rata-rata } \\
\text { akhir penelitian }(\mu \mathrm{g} / \mathrm{ml})\end{array}$ & $\begin{array}{c}\text { Pertumbuhan panjang relatif } \\
\text { rata - rata (transformasi } \mathrm{Y})\end{array}$ \\
\hline $\mathrm{A}(\mathrm{Kmp}: \mathrm{NPK}=0 \mathrm{gr} / 1: 2 \mathrm{gr} / \mathrm{l})$ & 0,001599 & $0,0156^{\mathrm{c}}$ \\
$\mathrm{B}(\mathrm{Kmp}: \mathrm{NPK}=0,5 \mathrm{gr} / 1: 1,5 \mathrm{gr} / \mathrm{l})$ & 0,001908 & $0,0235^{\mathrm{a}}$ \\
$\mathrm{C}(\mathrm{Kmp}: \mathrm{NPK}=1 \mathrm{gr} / 1: 1 \mathrm{gr} / \mathrm{l})$ & 0,001948 & $0,0243^{\mathrm{a}}$ \\
$\mathrm{D}(\mathrm{Kmp}: \mathrm{NPK}=1,5 \mathrm{gr} / 1: 0,5 \mathrm{gr} / 1)$ & 0,001874 & $0,0227^{\mathrm{ab}}$ \\
$\mathrm{E}(\mathrm{Kmp}: \mathrm{NPK}=2 \mathrm{gr} / 1: 0 \mathrm{gr} / \mathrm{l})$ & 0,001667 & $0,0177^{\mathrm{bc}}$ \\
$\mathrm{F}(\mathrm{Kmp}: \mathrm{NPK}=$ tanpa pupuk$)$ & 0,001440 & $0,0075^{\mathrm{c}}$ \\
\hline
\end{tabular}

Keterangan: Superskrip yang berbeda menunjukkan perbedaan $(\mathrm{p}<0,05)$

\section{Jumlah klorofil a Gracilaria verrucosa}

Hasil penghitungan Anova menunjukkan kombinasi pupuk kompos dan NPK berpengaruh nyata $(\mathrm{p}<0,05)$ terhadap jumlah klorofil $a G$. verrucosa. Hasil tersebut dilanjutkan dengan uji jarak berganda Duncan, yang menunjukkan bahwa kombinasi pupuk kompos dan NPK yang dapat memberikan jumlah klorofil $a$ G. verrucosa terbaik adalah perlakuan $\mathrm{C}$ (pupuk kompos dan NPK = $1 \mathrm{gr} / 1: 1 \mathrm{gr} / \mathrm{l})$ yang tidak berbeda nyata $(\mathrm{p}>0,05)$ dengan perlakuan B (pupuk kompos dan NPK $=0,5$ gr/l : 1,5 gr/l), perlakuan D (pupuk kompos dan $\mathrm{NPK}=1,5 \mathrm{gr} / 1: 0,5 \mathrm{gr} / \mathrm{l}$ ) dan perlakuan E (pupuk kompos dan NPK $=2 \mathrm{gr} / 1: 0 \mathrm{gr} / \mathrm{l})$. Hasil terendah diperoleh perlakuan $\mathrm{F}$ (tanpa pupuk) yang berbeda nyata $(\mathrm{p}<0,05)$ dengan perlakuan A (pupuk kompos 


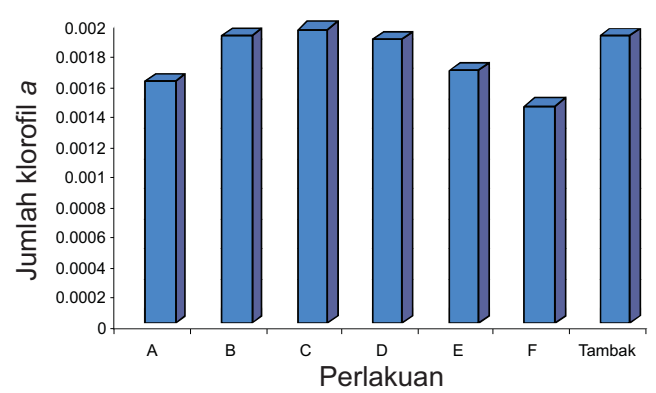

Gambar 3. Grafik jumlah klorofil a G.verrucosa (Ket : A : (Kmp : NPK = 0 gr/l : 2gr/l), B : (Kmp $: \mathrm{NPK}=0,5 \mathrm{gr} / 1: 1,5 \mathrm{gr} / 1), \mathrm{C}:(\mathrm{Kmp}: \mathrm{NPK}=1 \mathrm{gr} / 1: 1 \mathrm{gr} / 1), \mathrm{D}:(\mathrm{Kmp}: \mathrm{NPK}=1,5 \mathrm{gr} / 1$ : $0,5 \mathrm{gr} / \mathrm{l}), \mathrm{E}:(\mathrm{Kmp}: \mathrm{NPK}=2 \mathrm{gr} /: 0 \mathrm{gr} / \mathrm{l}), \mathrm{F}:$ tanpa pupuk$)$

Tabel 4. Hasil uji jarak berganda Duncan terhadap pertumbuhan panjang rata-rata G. verrucosa selama 35 hari

\begin{tabular}{|l|c|c|}
\hline \multicolumn{1}{|c|}{ Perlakuan } & $\begin{array}{c}\text { Kadar air rata-rata } \\
\text { akhir penelitian }(\%)\end{array}$ & $\begin{array}{c}\text { Kadar air rata-rata } \\
\text { (Transformasi } \sqrt{ } \text { Y) }\end{array}$ \\
\hline $\mathrm{A}(\mathrm{Kmp}: \mathrm{NPK}=0 \mathrm{gr} / 1: 2 \mathrm{gr} / \mathrm{l})$ & 29,70 & $1,55^{\mathrm{bc}}$ \\
$\mathrm{B}(\mathrm{Kmp}: \mathrm{NPK}=0,5 \mathrm{gr} / 1: 1,5 \mathrm{gr} / \mathrm{l})$ & 28,99 & $1,76^{\mathrm{ab}}$ \\
$\mathrm{C}(\mathrm{Kmp}: \mathrm{NPK}=1 \mathrm{gr} / 1: 1 \mathrm{gr} / \mathrm{l})$ & 28,48 & $1,90^{\mathrm{a}}$ \\
$\mathrm{D}(\mathrm{Kmp}: \mathrm{NPK}=1,5 \mathrm{gr} / 1: 0,5 \mathrm{gr} / 1)$ & 29,91 & $1,37^{\mathrm{bc}}$ \\
$\mathrm{E}(\mathrm{Kmp}: \mathrm{NPK}=2 \mathrm{gr} / 1: 0 \mathrm{gr} / \mathrm{l})$ & 30,28 & $1,31^{\mathrm{c}}$ \\
F (Kmp : NPK $=$ tanpa pupuk) & 30,39 & \\
\hline
\end{tabular}

Keterangan: Superskrip yang berbeda menunjukkan perbedaan $(\mathrm{p}<0,05)$

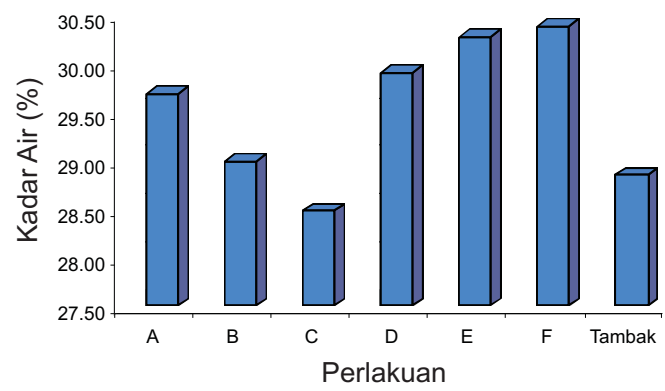

Gambar 4. Grafik jumlah klorofil a G.verrucosa (Ket : A : (Kmp : NPK = 0 gr/l : 2gr/l), B : (Kmp $: \mathrm{NPK}=0,5 \mathrm{gr} / 1: 1,5 \mathrm{gr} / \mathrm{l}), \mathrm{C}:(\mathrm{Kmp}: \mathrm{NPK}=1 \mathrm{gr} / 1: 1 \mathrm{gr} / 1), \mathrm{D}:(\mathrm{Kmp}: \mathrm{NPK}=1,5 \mathrm{gr} / 1$ : $0,5 \mathrm{gr} / \mathrm{l}), \mathrm{E}:(\mathrm{Kmp}: \mathrm{NPK}=2 \mathrm{gr} /: 0 \mathrm{gr} / \mathrm{l}), \mathrm{F}:$ tanpa pupuk$)$

dan NPK $=0$ gr/l $: 2 \mathrm{gr} / \mathrm{l})$. Hasil uji jarak berganda Duncan terhadap jumlah klorofil a G. verrucosa pada setiap perlakuan terdapat pada Tabel 3.

Grafik jumlah klorofil a G.verrucosa pada masingmasing perlakuan terdapat pada Gambar 2.

Kadar air Gracilaria verrucosa.

Hasil penghitungan Anova menunjukkan kombinasi pupuk kompos dan NPK berpengaruh nyata $(\mathrm{p}<0,05)$ terhadap kadar air G. verrucosa. Hasil tersebut dilanjutkan dengan uji jarak berganda Duncan, yang menunjukkan bahwa kombinasi pupuk kompos dan NPK yang dapat memberikan kadar air G. verrucosa terbaik adalah perlakuan $\mathrm{C}$ (pupuk kompos dan NPK $=1 \mathrm{gr} / 1$ : $1 \mathrm{gr} / \mathrm{l})$ yang tidak berbeda nyata $(\mathrm{p}>0,05)$ dengan perlakuan B (pupuk kompos dan NPK $=0,5$ gr/l : $1,5 \mathrm{gr} / \mathrm{l}$ ), perlakuan D (pupuk kompos dan NPK = $1,5 \mathrm{gr} / 1: 0,5 \mathrm{gr} / \mathrm{l}$ ) dan perlakuan A (pupuk kompos dan NPK $=0$ gr/l $: 2$ gr/l). Hasil terendah diperoleh perlakuan $\mathrm{F}$ (tanpa pupuk) yang tidak berbeda nyata $(\mathrm{p}<0,05)$ dengan perlakuan $\mathrm{E}$ (pupuk kompos dan $\mathrm{NPK}=2 \mathrm{gr} / 1: 0 \mathrm{gr} / \mathrm{l})$. Hasil uji jarak berganda Duncan terhadap kadar air G. verrucosa pada setiap perlakuan terdapat pada Tabel 4. 
Tabel 5. Data rata-rata kualitas air pemeliharaan G. verrucosa.

\begin{tabular}{|l|c|c|c|}
\hline \multicolumn{1}{|c|}{ Perlakuan } & Suhu $\left({ }^{0} \mathrm{C}\right)$ & $\mathrm{pH}$ & Salinitasi \%o \\
\hline $\mathrm{A}(0 \mathrm{gr} / 1: 2 \mathrm{gr} / 1)$ & 30,67 & 7 & 30 \\
$\mathrm{~B}(0,5 \mathrm{gr} / 1: 1,5 \mathrm{gr} / 1)$ & 30,33 & 6,83 & 30 \\
$\mathrm{C}(1 \mathrm{gr} / 1: 1 \mathrm{gr} / 1)$ & 29,50 & 6,83 & 30 \\
$\mathrm{D}(1,5 \mathrm{gr} / 1: 0,5 \mathrm{gr} / 1)$ & 30,17 & 6,83 & 30 \\
$\mathrm{E}(2 \mathrm{gr} / 1: 0 \mathrm{gr} / 1)$ & 30,33 & 7,33 & 30 \\
F (tanpa pupuk) & 29 & 7 & 30 \\
\hline
\end{tabular}

Kadar air rumput laut $G$. verrucosa pada penelitian ini diperoleh berdasarkan selisih jumlah kadar air pada akhir penelitian dan pada awal penelitian. Perlakuan kombinasi pupuk kompos dan NPK yang terbaik adalah perlakuan yang mengalami penurunan jumlah kadar air tertinggi.

\section{Kualitas air pemeliharaan Gracilaria verrucosa}

Parameter kualitas air yang diukur selama penelitian adalah suhu $\left({ }^{\circ} \mathrm{C}\right)$ dan $\mathrm{pH}$. Hasil pengukuran suhu selama penelitian pada setiap perlakuan dan ulangan yaitu berkisar antara 28-31 ${ }^{\circ} \mathrm{C}$. $\mathrm{pH}$ berkisar antara 6-8. Salinitas pada setiap perlakuan $30 \%$. Hasil pengukuran rata-rata kualitas air terdapat pada Tabel 5 .

Hasil penghitungan Anova menunjukkan kombinasi pupuk kompos dan NPK berpengaruh nyata $(\mathrm{p}<0,05)$ terhadap laju pertumbuhan berat harian G. verrucosa. Hasil tersebut dilanjutkan dengan uji jarak berganda Duncan, yang menunjukkan bahwa kombinasi pupuk kompos dan NPK yang dapat memberikan laju pertumbuhan berat harian $G$. verrucosa terbaik adalah perlakuan C (pupuk kompos dan NPK = 1gr/l : 1gr/l) yang berbeda nyata $(\mathrm{p}<0,05)$ dengan perlakuan $\mathrm{B}$ (pupuk kompos dan NPK =0,5 gr/l : 1,5 gr/l) dan perlakuan D (pupuk kompos dan NPK $=1,5 \mathrm{gr} / 1: 0,5 \mathrm{gr} / \mathrm{l}$ ). Hasil terendah diperoleh perlakuan F (tanpa pupuk) yang tidak berbeda nyata $(p>0,05)$ dengan perlakuan A (pupuk kompos dan NPK $=0$ gr/l : 2 gr/l) dan perlakuan $\mathrm{E}$ (pupuk kompos dan NPK $=2$ $\mathrm{gr} / 1: 0 \mathrm{gr} / 1)$.

Hasil penghitungan Anova menunjukkan kombinasi pupuk kompos dan NPK berpengaruh nyata $(\mathrm{p}<0,05)$ terhadap pertumbuhan panjang relatif G. verrucosa. Hasil tersebut dilanjutkan dengan uji jarak berganda Duncan yang menunjukkan bahwa kombinasi pupuk kompos dan NPK yang dapat memberikan laju pertumbuhan panjang harian G. verrucosa terbaik adalah perlakuan $\mathrm{C}$ (pupuk kompos dan NPK $=1 \mathrm{gr} / 1$ :
$1 \mathrm{gr} / 1)$ yang berbeda nyata $(\mathrm{p}<0,05)$ dengan perlakuan B (pupuk kompos dan NPK $=0,5 \mathrm{gr} / 1$ : $1,5 \mathrm{gr} / 1$ ), perlakuan $\mathrm{D}$ (pupuk kompos dan NPK = $1,5 \mathrm{gr} / 1: 0,5 \mathrm{gr} / \mathrm{l}$ ) dan perlakuan $\mathrm{E}$ (pupuk kompos dan NPK = 2 gr/l : 0 gr/l). Hasil terendah diperoleh perlakuan $\mathrm{F}$ (tanpa pupuk) yang berbeda nyata $(\mathrm{p}<0,05)$ dengan perlakuan A (pupuk kompos dan $\mathrm{NPK}=0 \mathrm{gr} / 1: 2 \mathrm{gr} / \mathrm{l})$.

Pada perlakuan C (pupuk kompos dan $\mathrm{NPK}=1 \mathrm{gr} / 1: 1 \mathrm{gr} / \mathrm{l})$ laju pertumbuhan berat harian dan pertumbuhan panjang relatif $G$. verrucosa sebesar 2,56\%/hari dan 2,21\%, yang berbeda nyata $(\mathrm{p}<0,05)$ dengan perlakuan B (pupuk kompos dan $\mathrm{NPK}=0,5 \mathrm{gr} / 1: 1,5 \mathrm{gr} / 1$ ) dengan laju pertumbuhan berat harian dan pertumbuhan panjang relatif $G$. verrucosa sebesar 1,86\%/hari dan 1,65\%. Hal ini disebabkan adanya perbedaan jumlah unsur hara makro dan mikro yang terdapat pada kombinasi pupuk. Diduga bahwa dengan pemberian kombinasi pupuk kompos dan NPK = 1gr/l : 1 gr/l, rumput laut efektif dalam menyerap nutrisi. Telah diketahui bahwa semua jenis tanaman sangat memerlukan adanya unsur hara, baik unsur hara makro maupun unsur hara mikro. Pada kombinasi pupuk kompos dan NPK terdapat delapan unsur hara (makro dan mikro) yang diperlukan bagi pertumbuhan tanaman. Mulyani (2002) dalam Silea dan Masitha (2005) menyatakan bahwa jika salah satu unsur hara tidak tersedia maka dapat menyebabkan pertumbuhan dan perkembangan tanaman serta produktivitas terhambat. Dengan rata-rata laju pertumbuhan harian sebesar 2,56\%/ hari dan pertumbuhan panjang relatif sebesar 2,21\%, rumput laut sudah dapat dilakukan pemanenan. Hal ini sesuai dengan pendapat Sulitijo (1985) yang menyatakan bahwa dengan laju pertumbuhan $2 \%$ /hari dalam waktu 35 hari sudah dapat dilakukan pemanenan.

Laju pertumbuhan berat harian dan pertumbuhan panjang relatif $G$. verrucosa pada perlakuan B (pupuk kompos dan NPK $=0,5 \mathrm{gr} / 1$ : $1,5 \mathrm{gr} / \mathrm{l}$ ), perlakuan D (pupuk kompos dan NPK = $1,5 \mathrm{gr} / 1$ : 0,5 gr/l), perlakuan A (pupuk kompos dan 
$\mathrm{NPK}=0 \mathrm{gr} / 1: 2 \mathrm{gr} / \mathrm{l})$ dan perlakuan $\mathrm{E}$ (pupuk kompos dan NPK $=2 \mathrm{gr} / 1$ : $0 \mathrm{gr} / \mathrm{l})$ kurang dari $2 \%$ dan tidak menunjukkan perbedaan $(\mathrm{p}>0,05)$ diantara perlakuan. Hal ini diduga disebabkan karena faktor lingkungan yang kurang mendukung pertumbuhan G. verrucosa. Faktor lingkungan yang diduga mempengaruhi pertumbuhan $G$. verrucosa pada perlakuan tersebut adalah wadah dan kedalaman wadah pemeliharaan. Diduga bahwa wadah dan kedalaman pemeliharaan yang kurang menyebabkan kurangnya ruang gerak bagi pertumbuhan G. verrucosa. Anam (2007) menyatakan bahwa kedalaman pada budidaya rumput laut adalah $50 \mathrm{~cm}$.

Hasil dari penelitian kombinasi pupuk kompos dan NPK terhadap laju pertumbuhan berat harian dan pertumbuhan panjang relatif $G$. verrucosa terendah pada perlakuan $\mathrm{F}$ (tanpa pupuk). Hal ini disebabkan tidak adanya unsur hara tambahan yang dibutuhkan oleh rumput laut. Penambahan unsur hara dapat menunjang pertumbuhan rumput laut. Salah satu faktor yang mempengaruhi pertumbuhan rumput laut adalah nutrien yang dapat diperoleh dari pupuk (Aslan,1998).

Uji nitrogen $(\mathrm{N})$ menunjukkan bahwa pada perlakuan C (pupuk kompos dan NPK = $1 \mathrm{gr} / 1$ : $1 \mathrm{gr} / \mathrm{l})$ memberikan hasil tertinggi. $\mathrm{N}$ merupakan komponen penting bagi pertumbuhan rumput laut (Anggadireja dkk., 2006). Hal ini disebabkan N merupakan faktor pembatas bagi pertumbuhan makrolaga (Hanisak, 1983). Novizan (2000) dalam Latif (2008) menyatakan bahwa pupuk N di dalam perairan menyebabkan tanaman tumbuh subur, sehingga produksinya meningkat. Hal ini sesuai dengan pendapat Lapointe and Tenore (1981) dalam Hanisak (1983) bahwa pertumbuhan makrolaga dapat distimulasi dengan penambahan $\mathrm{N}$ dalam media yang menggunakan sistem sirkulasi air laut. $\mathrm{N}$ berfungsi membantu proses pembentukan klorofil, fotosintesis, protein, lemak dan persenyawaan organik lainnya (Salundik dan Simamora, 2006).

Selain unsur $\mathrm{N}$, rumput laut juga membutuhkan unsur fosfor (P) dalam petumbuhannya. $\mathrm{P}$ berperan sebagai sumber nutrien bagi pertumbuhan rumput laut yang mudah terurai dan diserap tanaman (Odum, 1996 dalam Latif, 2008). P berfungsi memacu pertumbuhan dan mempercepat pembentukan spora rumput laut (Anam, 2007). Khul (1974) dalam Susanto dkk. (2001) menyatakan bahwa penambahan $\mathrm{P}$ diperlukan untuk pembentukan ATP dan berperan dalam penyerapan ion oleh alga.

Uji P menunjukkan bahwa pada perlakuan B (pupuk kompos dan NPK = 0,5 gr/1 : 1,5 gr/l) memberikan hasil tertinggi. Hal ini terjadi karena pupuk NPK yang digunakan pada penelitian ini mengandung unsur P sebesar 15\% yang jauh lebih tinggi daripada unsur $\mathrm{P}$ yang terkandung dalam kompos sebesar 1,06\%. Meskipun pada uji $\mathrm{P}$ menunjukkan bahwa perlakuan $\mathrm{C}$ (pupuk kompos dan NPK = $1 \mathrm{gr} / 1$ : 1gr/l) memberikan hasil tertinggi ketiga, tetapi jumlah P yang ada pada perlakuan $\mathrm{C}$ (pupuk kompos dan NPK = 1gr/l : 1gr/l) sudah dapat memberikan pengaruh yang baik untuk laju pertumbuhan berat harian dan pertumbuhan panjang relatif $G$. verrucosa.

Hasil penghitungan Anova pada penelitian kombinasi pupuk kompos dan NPK berpengaruh nyata $(\mathrm{p}<0,05)$ terhadap jumlah klorofil $a G$. verrucosa. Hasil uji jarak berganda Duncan menunjukkan bahwa kombinasi pupuk kompos dan NPK yang dapat memberikan jumlah klorofil $a$ G. verrucosa terbaik adalah perlakuan C (pupuk kompos dan NPK = $1 \mathrm{gr} / 1: 1 \mathrm{gr} / \mathrm{l}$ ) yang tidak berbeda nyata $(\mathrm{p}>0,05)$ dengan perlakuan B (pupuk kompos dan NPK $=0,5 \mathrm{gr} / 1: 1,5 \mathrm{gr} / \mathrm{l}$ ), perlakuan D (pupuk kompos dan NPK = 1,5 gr/l : 0,5 gr/l) dan perlakuan E (pupuk kompos dan NPK $=2 \mathrm{gr} / 1: 0 \mathrm{gr} / \mathrm{l}$ ). Hal ini menunjukkan bahwa pemberian kombinasi pupuk kompos dan NPK belum memberikan pengaruh yang berbeda terhadap jumlah klorofil $a G$. verrucosa antara perlakuan. Diduga bahwa tidak adanya perbedaan antara perlakuan, disebabkan karena cahaya yang masuk pada media pemeliharaan. Pada penelitian ini digunakan lampu fluoresecent 3000 lux dengan fotoperiod 12 jam terang 12 jam gelap. Telah diketahui bahwa proses fotosintesis memerlukan cahaya. Cahaya yang masuk ke dalam perairan, akan ditangkap oleh klorofil yang terdapat pada kloroplas tumbuhan. Kurangnya cahaya yang masuk ke dalam perairan juga mengakibatkan proses fotosintesis terhambat (Lawlor, 1993).

Faktor lain yang juga dibutuhkan untuk pembentukan klorofil a adalah nutrien. Aslan (1998) menyatakan bahwa pertumbuhan dan perkembangan rumput laut membutuhkan kualitas cahaya serta nutrien yang cukup seperti nitrat dan fosfat. Nitrat dan fosfat diperlukan sebagai bahan dasar penyusun protein dan pembentukan klorofil dalam proses fotosintesis. Nitrat dan fosfat dapat berasal dari pupuk. Uji $\mathrm{N}$ menunjukkan bahwa jumlah klorofil $a$ meningkat seiring dengan meningkatnya kandungan $\mathrm{N}$ dalam kombinasi 
pupuk. Hal tersebut juga didukung oleh penelitian yang dilakukan oleh Dong et al., (1990) yang menunjukkan bahwa pemberian $\mathrm{N}$ pada rumput laut Laminaria japonica dapat meningkatkan jumlah klorofil $a$. Lobban and Harrison (1994) dalam Kim et al. (2007) menyatakan bahwa sintesis klorofil a dan phycoerythrin memerlukan N. Selain N dan P, pembentukan klorofil a juga dipengaruhi oleh Magnesium (Mg). Mg merupakan unsur yang membentuk struktur klorofil dan berperan dalam penangkapan cahaya dalam proses fotosintesis (Lawlor, 1993).

Hasil dari penelitian kombinasi pupuk kompos dan NPK terhadap jumlah klorofil $a$ terendah pada perlakuan F (tanpa pupuk). Hal ini dikarenakan tidak adanya penambahan unsur hara ke dalam media pemeliharaan. Denault et al., (2000) juga menyatakan bahwa jumlah klorofil $a$ menurun seiring dengan menurunnya hara pada media pemeliharaan. Kurangnya unsur hara dapat menyebabkan proses fotosintesis terhambat dan berpengaruh terhadap jumlah klorofil (Latif, 2008).

Hasil penghitungan Anova menunjukkan kombinasi pupuk kompos dan NPK berpengaruh nyata $(\mathrm{p}<0,05)$ terhadap kadar air G. verrucosa. Hasil uji jarak berganda Duncan menunjukkan bahwa kombinasi pupuk kompos dan NPK yang dapat memberikan kadar air G. verrucosa terbaik adalah perlakuan $\mathrm{C}$ (pupuk kompos dan NPK = 1 gr/l : $1 \mathrm{gr} / \mathrm{l})$ yang tidak berbeda nyata $(\mathrm{p}>0,05)$ dengan perlakuan B (pupuk kompos dan NPK $=0,5 \mathrm{gr} / 1$ : $1,5 \mathrm{gr} /$ ), perlakuan D (pupuk kompos dan NPK = $1,5 \mathrm{gr} / 1: 0,5 \mathrm{gr} / \mathrm{l}$ ) dan perlakuan A (pupuk kompos dan NPK $=0 \mathrm{gr} / 1: 2 \mathrm{gr} / \mathrm{l}$ ). Hal ini menunjukkan bahwa pemberian kombinasi pupuk memberikan pengaruh yang relatif sama terhadap kadar air.

Pada penelitian ini, penambahan pupuk akan menyebabkan adanya penyerapan unsur hara oleh rumput laut, sehingga menambah nutrien, yang menyebabkan pertumbuhan sel. Pertumbuhan tersebut akan mengakibatkan peningkatan hasil metabolisme primer dan sekunder, yang ditunjukkan dengan pembesaran sel dan penebalan pada dinding sel. Penebalan akan menyebabkan adanya tekanan internal dalam sel. Tekanan internal dalam sel menyebabkan larutan di dalam sel akan terdorong keluar. Hal ini bertujuan untuk menjaga keseimbangan metabolisme di dalam sel. Salah satu larutan yang mudah keluar adalah air. Keluarnya air dari dalam sel menyebabkan kandungan air di dalam sel menurun (Manitto, 1981).

Kadar air dalam tanaman mempunyai hubungan dengan tekanan turgor dalam jaringan tanaman dan akan berpengaruh pada proses fotosintesis (Bryce and Hill, 1999). Harben and Kuvart (1996) dalam Hafara (2007) menyatakan bahwa $\mathrm{K}^{+}$penting untuk fotosintesis dan pengangkutan gula, efesiensi penggunaan air (berhubungan dengan kadar air), metabolisme karbonat dan protein, aktivasi enzim dan menjaga kualitas tanaman. Unsur $\mathrm{K}^{+}$ini dipenuhi dari pupuk NPK, karena kalium $(\mathrm{K})$ diserap dalam bentuk ion $\mathrm{K}^{+}$(Lingga dan Marsono, 2007).

$\mathrm{K}^{+}$berperan dalam banyak proses fisiologis dan biokimia tanaman dan diserap secara aktif dengan penyerapan yang tinggi. Kecepatan penyerapan $\mathrm{K}^{+}$dikontrol oleh $\mathrm{K}^{+}$yang terdapat di dalam sel dan berakibat pada turgor sel. Pada siang hari akan berlangsung fotosintesis, yang menghasilkan energi untuk mendorong peningkatan penyerapan $\mathrm{K}^{+}$yang akhirnya akan meningkatkan konsentrasi $\mathrm{K}^{+}$dan menaikkan tekanan turgor. Turunnya tekanan turgor pada kondisi stres air menyebabkan tanaman lembek. Defisiensi $\mathrm{K}^{+}$ berakibat pada penurunan laju pertumbuhan dan meningkatkan resistensi tanaman terhadap penyakit (Sumadi, 2007).

Parameter kualitas air yang diukur selama penelitian adalah suhu $\left({ }^{\circ} \mathrm{C}\right)$ dan $\mathrm{pH}$. Suhu merupakan salah satu faktor yang penting bagi pertumbuhan rumput laut (Raikar et al., 2001). Hal ini disebabkan suhu mempengaruhi aktivitas metabolisme dan perkembangan suatu organisme (Sahabuddin dan Tangko, 2008). Hasil pengukuran suhu selama penelitian berkisar antara $28-31^{\circ} \mathrm{C}$. Aslan (1998) menyatakan bahwa suhu yang baik untuk pertumbuhan rumput laut berkisar antara 26$33^{\circ} \mathrm{C}$. Raikar et al. (2001) menyatakan bahwa suhu di bawah $25^{\circ} \mathrm{C}$ terjadi penurunan pertumbuhan pada Gracilaria sp.

Salinitas yang terukur selama penelitian berkisar antara 30\%. Chen (1994) menyatakan bahwa salinitas optimal bagi pertumbuhan Gracilaria adalah 20-35\%. Perubahan salinitas akan menyebabkan adanya turgor antara bagian dalam dan luar rumput laut (Luning, 1990). Penurunan dan peningkatan salinitas di atas batas optimum tidak menyebabkan kematian, tetapi mengakibatkan rumput laut kurang elastis, mudah patah dan pertumbuhan akan terhambat (Syafruddin, 1993 dalam Latif, 2008).

Power of Hydrogen $(\mathrm{pH})$ adalah suatu ukuran dari konsentrasi ion hidrogen dan menunjukkan sifat asam atau basa suatu perairan (Summerfelt, 1997). Power of Hydrogen $(\mathrm{pH})$ air selama penelitian berkisar antara 6-8. Aslan (1998) 
menyatakan bahwa $\mathrm{pH}$ optimum bagi budidaya rumput laut berkisar antara 6,8-8,2. Kualitas air pemeliharaan $G$. verrucosa selama penelitian dapat disimpulkan masih layak dan sesuai kebutuhan hidup G. verrucosa.

\section{Kesimpulan}

Kombinasi pupuk kompos dan NPK berpengaruh nyata $(\mathrm{p}<0,05)$ terhadap laju pertumbuhan berat harian rata-rata dan pertumbuhan panjang relatif $G$. verrucosa. Kombinasi pupuk kompos dan NPK terhadap laju pertumbuhan berat harian dan pertumbuhan panjang relatif $G$. verrucosa yang memberikan hasil tertinggi terdapat pada perlakuan $\mathrm{C}$ (pupuk kompos dan NPK $=1 \mathrm{gr} / 1: 1 \mathrm{gr} / \mathrm{l})$. Kombinasi pupuk kompos dan NPK terhadap jumlah klorofil $a$ $G$. verrucosa yang memberikan hasil tertinggi terdapat pada perlakuan C (pupuk kompos dan NPK $=1 \mathrm{gr} / 1: 1 \mathrm{gr} / \mathrm{l})$ dan memberikan pengaruh relatif sama di antara perlakuan. Kombinasi pupuk kompos dan NPK terhadap kadar air G. verrucosa yang memberikan hasil terendah terdapat pada perlakuan $\mathrm{C}$ (pupuk kompos dan NPK $=1 \mathrm{gr} / 1$ : $1 \mathrm{gr} / \mathrm{l})$ dan memberikan pengaruh relatif sama di antara perlakuan .

Pada budidaya rumput laut, untuk meningkatkan laju pertumbuhan harian dan pertumbuhan panjang relatif $G$. verrucosa dapat digunakan kombinasi pupuk kompos dan NPK (1 gr/1 : $1 \mathrm{gr} / 1)$.

\section{Daftar Pustaka}

Anam, M. S. 2007. Petunjuk Budidaya Polikultur Rumput Laut, Bandeng dan Udang di Tambak. Kantor Ketahanan Pangan dan Penyuluhan Pertanian Kabupaten Pasuruan. hal 3. Anggadireja, J. T., A. Zatnika., H. Purwoto dan S. Istini. 2006. Rumput Laut. Penebar Swadaya. Jakarta. hal. 39-47.

Anggadireja, J. T., A. Zatnika., H. Purwoto dan S. Istini. 2006. Rumput Laut. Penebar Swadaya. Jakarta. hal. 39-47.

Aslan, L. M. 1998. Rumput Laut. Kanisius. Jakarta. hal. 13-37.

Bryce, J. H and S. A. Hill. 1999. Energy Production in Plant Cells. In : Lea P. J and Leegood, R. C. Plant Biochemistry and Molecular Biology. Second Edition. John Wiley and Sons Ltd. England. p. 2-6.

Chen, J. X. 1994. Gracilaria Culture in China. http://www.fao.org. 12/6/2008. 7 pp.Denault, M., E. Stieve and I. Valiela. 2000. Effects of
Nitrogen Load and Irradiance on Photosynthetic Pigment Concentration in Cladophora vagabunda and Gracilaria tikhivae in Estuaries of Waquoit Bay. Biology Bulletins. 199 : 223-225.

Dong, L., L. Guangheng and W. Chaoyuan. 1990. Effect of NH4N on The Pigment Content of Laminaria Japonica. Chinese Journal of Oceanology and Limnology. 8 (2) : 128-134.

Hafara, A. Potasium. http://www.hafara.com. 29/01/2009. 2 hal.

Hanisak, 1983. The Nitrogen Relationhips of Marine Macroalgae. In : Carpenter, E. J and D. G. Capone. Nitrogen in The Marine Environment. Academic Press Inc. New York. p. 703.

Indriani, 2000. Membuat Kompos Secara Kilat. Penebar Swadaya. Jakarta. hal.4.

Kim, J. K., G. P. Kreamer, C. D. Neefus, I. K. Chung and C. Yarish. 2007. Effect of Temperature and Ammonium on Growth, Pigment Production and Nitrogen Uptake by Four Species of Porphyra (Bangiales, Rhodophyta) Native to The New England Coast. Journal of Applied Phycology. $19: 431-440$.

Latif, I. 2008. Pengaruh Pemberian Pupuk Terhadap Pertumbuhan, Produksi dan Kandungan Karageenan Rumput Laut Kappaphychus striatum. http://www.unhas.ac.id.12/01/2009. 4 hal.

Lawlor, D. W. 1993. Photosynthesis. 2nd Edition. Longman Group UK Limited. London. p. 9-23.

Lewmanomont, K. 1995. A Review Paper on The Taxonomy of Gracilaria in Asian Countries. http://www.fao.org.12/6/2008. $11 \mathrm{pp.}$

Lingga, P. dan Marsono. 2007. Petunjuk Penggunaan Pupuk. Penebar Swadaya. Jakarta. hal. 13-36

Manitto, P. 1981. Biosintesis Produk Alami. Terjemahan : Koensoemardiyah. IKIP Semarang Press. Semarang. hal 2-16.

Raikar, S. V, M. Lima and Y. Fujita. 2001. Effect of Temperature, Salinity and Light Intensity on the Growth of Gracilaria spp. (Gracilariales, Rhodophyta) from Japan, Malaysia and India. Journal of Marine Sciences. 30 : 98-104.

Sahabuddin dan A. M. Tangko. 2008. Pengaruh Jarak Lokasi Budidaya Dari Garis Pantai Terhadap Pertumbuhan dan Kandungan Karaginan Rumput Laut Eucheuma cottoni. Seminar Nasional Kelautan IV, 24 April 2008. Surabaya. 4 hal. 
Salundik dan Simamora, S. 2006. Meningkatkan Kualitas Kompos. Agromedia Pustaka. Jakarta. hal.10.

Silea. J. L. M dan L. Masitha. 2005. Penggunaan Pupuk Bionik pada Tanaman Rumput Laut (Eucheuma sp.). http://www.unidayan.ac.id. 20/01/2009. 5 hal.

Sulitijo. 1985. Budidaya Rumput Laut. http://www.fao.org.21/01/2009. 7 hal.

Sumadi. 2007. Nutrien Mineral. http://www. elearning.unej.ac.id. 19/05/2009. 7 hal.
Summerfelt, R. C. 1997. Water Quality Considerations for Aquaculture. http://www.aquanic.org. 12/12/2008.8 pp.

Susanto, A. B., Sardjito., A. Djunaedi dan Safuan. 2001. Studi Aplikasi Teknik Semprot dengan Penambahan Nutrien dalam Budidaya Rumput Laut Gracilaria verrucosa (Huds) Papenf. http://nakula.rvs.uni-biefeld.de. 30/07/2008. 4 hal. 